\title{
ANALISIS KELAYAKAN PEMBUKAAN PRODI BARU TERINTEGRASI KEBUTUHAN PASAR DI LINGKUNGAN GRESIK DENGAN PENDEKATAN STATISTIK
}

\author{
Efta Dhartikasari* \\ Program Studi Teknik Industri, Fakultas Teknik, Universitas Muhammadiyah Gresik \\ Email: eftadhartikasari@umg.ac.id
}

Artikel masuk : 20-07-2020

Artikel direvisi : 26-09-2020
*Penulis Korespondensi

Artikel diterima : 05-11-2020

\begin{abstract}
Abstrak -- Dalam menghadapi persaingan bisnis yang tak menentu, sudah bukan rahasia lagi jika semua pelaku bisnis menyajikan yang terbaik untuk kebutuhan customernya. Hal tersebut juga berlaku dalam bisnis perguruan tinggi. Pelaku bisnis perguruan tinggi akan lebih mengutamakan pelayanan dan pengembangan prodi, agar lebih dipercaya oleh masyarakat. Semakin banyak prodi yang dibuka maka akan semakin banyak juga pilihan untuk calon mahasiswa. Sayangnya tidak semua prodi yang dibuka ternyata memiliki prospek pekerjaan yang baik. Penelitian ini akan menyajikan analisa tentang inkubator bisnis pendidikan di daerah Gresik. Dinamakan inkubator karena disini calon mahasiswa sebagai input, kampus sebagai proses dan output adalah perusahaan sendiri diasumsikan semua terjadi di Gresik, tidak ada output yang keluar. Konsep dari penelitian ini adalah adanya integrasi antara minat calon mahasiswa memilih program studi dan kebutuhan akan pasar atau perusahaan sendiri. Penelitian ini mengambil sampel sebanyak 100 responden yang dipilih dari kalangan siswa-siswi Gresik yang diminta untuk merating prodi yang paling diminati dan tidak yang didapat dari seluruh prodi yang berada di Universitas di Gresik dan ditambah beberapa prodi di beberapa Fakultas, sehingga disini tidak ada prodi yang sama sekali tidak diminati. Data kedua adalah tentang kebutuhan akan lowongan kerja, prodi apa saja yang mereka butuhkan. Beberapa analisa statistik digunakan untuk support asumsi penyesuaian data. Sedangkan Analytical Hierarchy Process digunakan untuk menghitung rating bobot kebutuhan lulusan akan pekerjaan kemudian akan diintegrasikan akan minat masuk mahasiswa. Hasilnya adalah rank prodi paling diminati calon mahasiswa dan penyerapan tenaga kerja adalah Prodi Farmasi, Pendidikan Dokter dan IImu Gizi yang keseluruhan berada pada cluster IImu Kesehatan.
\end{abstract}

Kata kunci: Analytical Hierarchy Process; Mahasiswa; Statistik

\begin{abstract}
In the face of uncertain business competition, it is no secret that all business people present the best for their customers' needs. This also applies to the college business. To be trusted by many groups, university business people always improve services and study program development. The more study programs opened, the more choices there will be for prospective students. Unfortunately, not all study programs opened have good job prospects. This research will present an analysis of the education business incubator in the Gresik area. It is called an incubator because here prospective students are input, the campus as a process and output is the company itself; it is assumed that everything happens in Gresik, no result comes ou; noo there must be an integration between the interests of prospective students choosing study programs and the needs of the market or the company itself. This study took a sample of 100 respondents selected from the Gresik students who were asked to rate the most desirable study programs and those not obtained from all study programs at the University in Gresik and added several study programs in several faculties, so that there are no study programs not at all in demand. The second data is about the need for job openings, what study programs they need. Some statistical analyzes are used to support the assumption of data adjustment. In comparison, the Analytical Hierarchy Process is used to calculate the weight of graduates' needs for work and will then be integrated into student interest. The result is that the rank of study programs most desirable for prospective students and employees is the Department of Pharmacy, Medical Education, and Nutrition.
\end{abstract}

Keywords: Analytical Hierarchy Process; Students; Statistics 


\section{PENDAHULUAN}

Dalam rangka menghadapi persaingan bisnis, layaknya perusahaan perlu mempertahankan dan meningkatkan kualitas. Kualitas tak hanya dipandang dari sisi produk tetapi juga jasa. Pada tahapan ini, penelitian yang dikembangkan akan mengarah pada produk, yakni semakin beragamnya prodi yang dibuka. Macam-macam program studi yang dibuka oleh sebuah Universitas bertujuan untuk menjawab tantangan kebutuhan pasar.

Sayangnya tidak semua program studi yang dibuka dibutuhkan oleh perusahaan. Ada aspek produsen dan konsumen, dimana siswa siswi SMA/SMK harus mengenyampingkan ego dengan lebih mengedepankan kebutuhan pasar daripada ambisi untuk terjun ke program studi yang diinginkan. Jika program studi yang dituju tidak memiliki prospek yang baik, pada hakikatnya siswa siswi harus memilih beberapa alternatif untuk menentukan pilihan.

Dalam penelitian ini akan dilakukan proses inkubator produsen dan konsumen dalam bidang pendidikan. Kenapa inkubator, karena disini peneliti mengasumsikan siswa-siswi yang melakukan perangkingan pada beberapa program studi yang dipilih berasal dari Gresik, akan melanjutkan pendidikan di Gresik dan bekerja di Gresik. Sehingga disini tidak ada plot yang keluar dari batas kontrol yakni daerah Gresik.

Analisa kelayakan program studi sudah banyak sekali dilakukan, tetapi dari mereka hanya membahas mengerucut pada satu program studi. Apakah satu program studi tersebut layak dibuka di suatu Universitas atau tidak. Seperti yang dilakukan oleh (Soekiyono et al., 2014), dengan menggunakan dengan Statistika Deskriptif menghasilkan Program Studi Perhotelan Layak dibuka Di UT. Basis penelitian tentang studi kelayakan pembukaan prodi baru banyak mengerucut pada satu program studi (Masykuroh et al., 2019; Satyawan et al., 2020) dan belum menjalar ke banyak program studi. Padahal bisa saja seorang siswa memiliki perangkingan sendiri dalam menentukan prioritas dimana dia memiliki program studi untuk studi lanjutnya.

Penelitian ini akan membuat konsep input, proses dan output dalam sebuah inkubator yakni di wilayah Gresik. Dimana disini diasumsikan seharusnya input yang dihasilkan oleh proses harus bisa ditangkap oleh output. Artinya mahasiswa yang lulus dari sebuah Universitas di Gresik seharusnya bisa mendapatkan pekerjaan di Gresik, sehingga tidak ada aspek terbuang karena salah pemilihan program studi mereka tidak mendapat pekerjaan. Penelitian ini ditujukan untuk menjawab permasalahan yang ada di Universitas di Gresik dengan cara menentukan program studi apa yang seharusnya dibuka menurut aspek keinginan calon mahasiswa dan kebutuhan pasar sendiri yakni perusahaan sehingga mahasiswa yang masuk atau dikelola oleh suatu Universitas bisa mendapatkan pekerjaan. Analisa dengan pendekatan AHP akan ditujukan untuk membantu proses penelitian ini. AHP merupakan salah satu alat untuk mendapatkan perangkingan terbaik dari aspek kebutuhan pasar yakni perusahaan dan keinginan dari calon mahasiswa, dan gap antar keduanya dalam sebuah inkubator adalah sasaran penelitian ini.

\section{METODE PENELITIAN}

Penelitian ini akan menggunakan beberapa metode untuk menganalisa kelayakan pembukaan prodi baru. Model konseptual inkubator dari konsep input-proses-output yang dianalisis untuk pendidikan perguruan tinggi di wilayah Gresik (Gambar 1). Konsep ini memperlihatkan konsep bahwa pendidikan tinggi tak hanya mementingkan kebutuhan akan minat mahasiswa masuk akan prodi yang dituju, tetapi juga mementingkan akan aspek kebutuhan perusahaan. Sehingga ada win win antar calon mahasiswa dan kebutuhan perusahaan dengan Universitas sebagai wadah untuk mendidik mahasiswa.

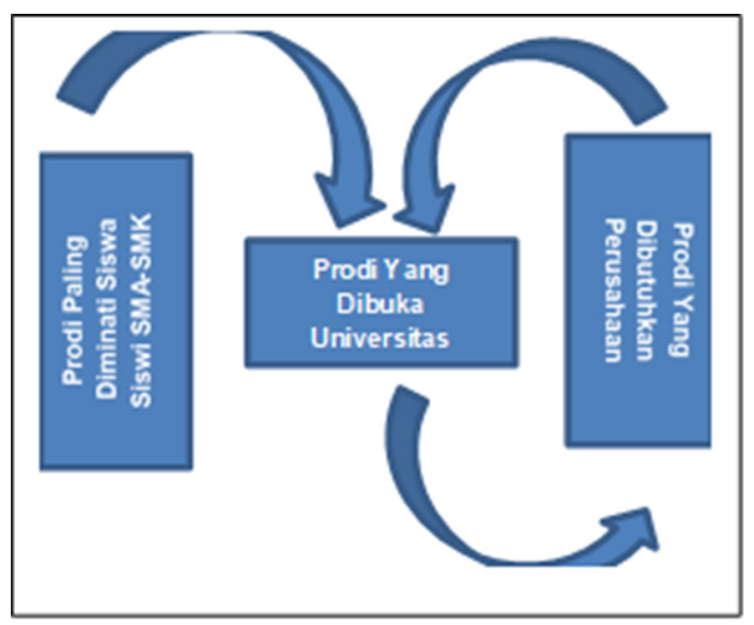

Gambar 1. Model Konseptual

Penelitian ini akan menggunakan beberapa alur penelitian. Pertama peneliti akan memeriksa beberapa Fakultas di seluruh Universitas di Gresik dan menambahkan program studi apa yang belum dibuka (Tabel 1). Kedua akan dilakukan analisis deskriptif untuk menentukan program studi paling diminati hingga paling tidak diminati dan statistika deskriptif tentang kebutuhan perusahaan akan program studi tersebut. Selanjutnya akan dibuat kelompok pekerjaan, karena banyaknya pekerjaan 
dari perusahaan maka akan dibuat kelompok pekerjaan dan dianalisis program studi apa yang paling dibutuhkan perusahaan. Ketiga adalah membuat cluster analisis dari kelompok pekerjaan untuk mencari karakteristik bersesuaian antar kelompok pekerjaan. Keempat adalah analisis regresi untuk mengetahui model hubungan antara minat calon mahasiswa dan perusahaan.

Tabel 1. Rekomendasi Program Studi

\begin{tabular}{|c|c|c|c|}
\hline \multicolumn{2}{|r|}{ Fakultas Pertanian } & \multicolumn{2}{|c|}{ Fakultas Hukum } \\
\hline \# & Teknologi Pangan & $\#$ & Hukum \\
\hline \# & Akuakultur & \multicolumn{2}{|c|}{$\begin{array}{c}\text { Fakulatas Ekonomi dan } \\
\text { Bisnis }\end{array}$} \\
\hline \# & Agroteknologi & $\#$ & Akutansi \\
\hline \# & Agribisnis & $\#$ & Management \\
\hline+ & $\begin{array}{c}\text { Management } \\
\text { Sumber Daya Lahan }\end{array}$ & $\#$ & Kewirausahaan \\
\hline+ & $\begin{array}{l}\text { Agronomi \& } \\
\text { Holtikultura }\end{array}$ & + & $\begin{array}{c}\text { Ekonomi } \\
\text { Pembangunan }\end{array}$ \\
\hline+ & Proteksi Tanaman & + & Ekonomi Islam \\
\hline \multicolumn{2}{|c|}{$\begin{array}{l}\text { Fakultas Keguruan \& } \\
\text { IImu Pendidikan }\end{array}$} & \multicolumn{2}{|r|}{ Fakultas Teknik } \\
\hline \# & $\begin{array}{l}\text { Pendidikan } \\
\text { Matematika }\end{array}$ & \# & Kimia \\
\hline \# & $\begin{array}{l}\text { Pendidikan Bhs. } \\
\text { Inggris }\end{array}$ & $\#$ & Elektro \\
\hline \# & PGSD & $\#$ & Sipil \\
\hline+ & $\begin{array}{c}\text { Pendidikan Luar } \\
\text { Biasa }\end{array}$ & $\#$ & Industri \\
\hline+ & $\begin{array}{c}\text { Pendidikan Anak } \\
\text { Usia Dini }\end{array}$ & $\#$ & T.Perkapalan \\
\hline \multicolumn{2}{|c|}{ Fakultas Agama Islam } & \# & Informatika \\
\hline \# & $\begin{array}{c}\text { Pendidikan Agama } \\
\text { Islam }\end{array}$ & + & Mesin \\
\hline \# & PIAUD & + & Sistem Informasi \\
\hline+ & $\begin{array}{l}\text { Management } \\
\text { Dakwah }\end{array}$ & + & $\begin{array}{c}\text { Multimedia dan } \\
\text { Jaringan }\end{array}$ \\
\hline T & $\begin{array}{l}\text { Pengembangan } \\
\text { Masyarakat islam }\end{array}$ & \multicolumn{2}{|c|}{ Fakultas Kesehatan } \\
\hline \multicolumn{2}{|r|}{ Fakultas Psiologi } & \multirow{2}{*}{\multicolumn{2}{|c|}{$\begin{array}{c}\text { Kesehatan } \\
\text { Masyarakat } \\
\text { Profesi NERS } \\
\text { (tidak digunakan) }\end{array}$}} \\
\hline \# & Psikologi Industri & & \\
\hline+ & Psikologi Klinis & $\#$ & Kebidanan \\
\hline+ & $\begin{array}{l}\text { Psikologi dan } \\
\text { Organisasi }\end{array}$ & \# & Ilmu Gizi \\
\hline+ & Psikologi Sosial & $\#$ & Keperawatan \\
\hline \multirow{4}{*}{\multicolumn{2}{|c|}{$\begin{array}{l}\text { Keterangan: } \\
\text { \# program studi studi } \\
\text { sudah dibuka } \\
\text { + program studi yang } \\
\text { direkomendasikan }\end{array}$}} & \# & Farmasi \\
\hline & & $\#$ & Fisioterapi \\
\hline & & + & Pendidikan Dokter \\
\hline & & + & Pendidikan Bidan \\
\hline
\end{tabular}

Penelitian berkaitan dengan sistem pendukung keputusan tentang pemilihan program baru menganalisa keputusan empat kriteria yakni prospek kerja, daya tampung, jumlah, pendaftaran dan akreditasi yang dibangun dengan bahasa pemrograman berbasis web PHP dan MySQL sebagai database. Hasilnya adalah berupa rekomendasi peringkat program studi yang ada di UIN Sunan Kalijaga (Permana, 2013). Sistem pendukung keputusan dengan metode black box menjadi alat bantu untuk memudahkan dalam pengelolaan hasil tes, serta pemilihan jurusan di UIN Alauddin (Syafar, 2018). Sistem Decision Support System juga efektif dalam membantu pengambilan keputusan terkait dengan pembukaan prodi S2 (Wahyudi et al., 2012). Kekurangan dari penelitian tersebut adalah hanya memikirkan prospek yang ada di intern kampus, tetapi belum mempertimbangkan prospek kerja yang dibatasi. Padahal dalam kenyataannya, prospek kerja terbatas. Sehingga penelitian yang diajukan dalam lingkup inkubator input-prosesoutput dapat memberikan sumbangsih bagi perguruan tinggi untuk menimbang program studi apa yang bersesuaian dengan prospek pasar yang harus dibuka tetapi tidak mengesampingkan keinginan daripada calon mahasiswa sendiri.

\section{Statistika Deskriptif}

Statistika Deskriptif adalah metode-metode yang digunakan dalam statistik secara visual atau garis besar untuk menghasilkan kesimpulan. Kesimpulan disini bisa saja bersifat sementara karena data hanya dilihat berdasarkan gambaran secara garis besar (Walpole \& Myers, 1995).

Cluster analisis merupakan salah satu tools statistika yang masuk dalam golongan analisis multivariate. Tujuan utamanya adalah pengelompokkan variabel berdasarkan karakteristik yang ada.berikut adalah tahapan dari cluster analisis (Ediyanto \& Satyahadewi, 2013).

1. Mengukur kesamaan antar objek (similarity)

$\checkmark$ Mengukur korelasi antar sepasang objek pada beberapa variabel.

$\checkmark$ Mengukur jarak (distance) antara dua objek (euclidean distance)

\section{Membuat cluster}

Metode yang digunakan disini adalah hierarchical method yakni mengelompokkan dengan dua atau lebih objek yang memiliki kesamaan paling dekat. Kemudian proses diteruskan ke objek lain yang memiliki kedekatan kedua, dan seterusnya hingga membentuk pohon hirarki atau lebih dikenal dengan dendogram.

Analisis regresi merupakan salah satu tools statistik yang masuk bagian multivariate yang mempelajari tentang hubungan variabel dependent dan independent (Gudono, 2011; Hair et al., 2010). Pada kasus ini digunakan analisis regresi linier dengan minat mahasiswa masuk sebagai variabel dependent dan kebutuhan perusahaan atas program studi sebagai variabel 
independent (Drapper \& Smith, 1992; Supranto, 2004).

Dalam analisa regresi akan dibentuk suatu model regresi, dalam hal ini penelitian menggunakan metode analisis regresi sederhana yakni satu peubah bebas $(\mathrm{X})$ dan satu peubah tak bebas $(\mathrm{Y})$ dengan a adalah intersep dan $b$ merupakan koefisien beta.

$\mathrm{Y}=\mathrm{a}+\mathrm{bx}$

\section{Analytical Hierarchy Process (AHP)}

AHP merupakan salah satu analisa pendukung keputusan yang dikembangkan oleh Professor Thomas L.Saaty. Metode ini akan membuat urutan alternatif keputusan dan pemilihan analisa terbaik pada saat pengambilan keputusan dan pemilihan alternatif terbaik pada saat pengambilan keputusan dengan beberapa kriteria untuk pengambilan keputusan tertentu. Hirarki disini akan membuat suatu masalah yang kompleks dan tidak terstruktur dapat dipecahkan ke dalam kelompoknya, kemudian kelompokkelompok tersebut diatur menjadi suatu bentuk hirarki (Marsono, 2020).

Prosedur daripada AHP adalah sebagai berikut (Saaty, 1990).

1. Mendefinisikan masalah dan menentukan alternatif solusi

2. Membuat model permasalahan dalam hierarki yang meliputi tujuan, alternatif solusi untuk mencapai tujuan, serta kriteria dan sub-kriteria untuk evaluasi alternatif.

3. Membuat skala prioritas antar kriteria.

4. Menghitung bobot kriteria dan sub-kriteria. Bobot disini ada bobot lokal (local weight) dan bobot global (global weight) (Forman \& Gass, 2001).

\section{HASIL DAN PEMBAHASAN \\ Statistika Deskriptif}

Perangkingan 43 prodi dari paling tertarik ke paling tidak tertarik yang diberikan 100 siswasiswi SMA/SMK yang akan melanjutkan ke jenjang perkuliahan. Hasil pengolahan data menunjukkan Prodi Farmasi adalah prodi paling diminati oleh siswa-siswi SMA/SMA yang akan melanjutkan ke jenjang lebih tinggi (Gambar 2). 10 prodi paling kurang diminati oleh perangkingan yang diberikan 100 siswa siswi Gresik yang ingin melanjutkan perkuliahan (Gambar 3). Dengan Management Dakwah menduduki peringkat paling terakhir, yang artinya paling tidak diminati atau pilihan paling terakhir dari perangkingan oleh 100 siswa siswi SMA/SMK Gresik. Prodi Teknik Industri adalah prodi paling dicari dari banyaknya jenis lapangan kerja 10 perusahaan besar di Gresik pada tahun 2019 (Gambar 5), kemudian disusul oleh Prodi Teknik Elektro dan Management/Teknik Mesin. Dari 10 perangkingan yang ada, 5 prodi berasal dari Fakultas Teknik. Sehingga jika dilihat dari segi banyaknya jenis lapangan kerja perusahaan di Gresik, Fakultas Teknik paling recomended dibandingkan fakultas lain.

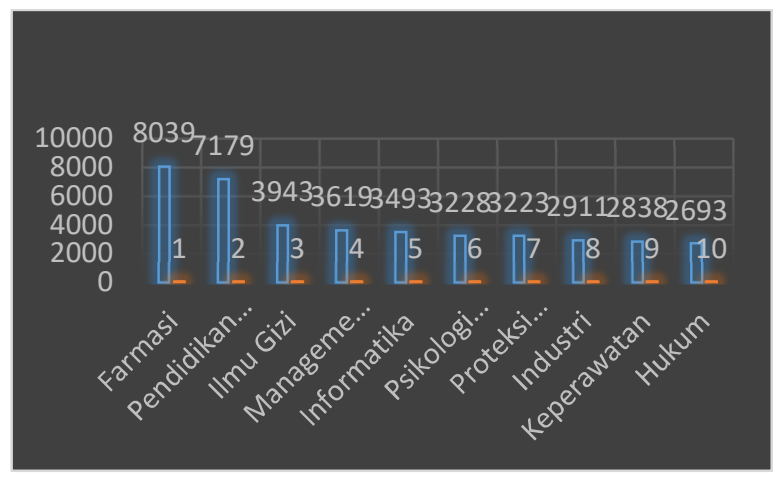

Gambar 2. 10 Prodi Paling Diminati dalam Perangkingan

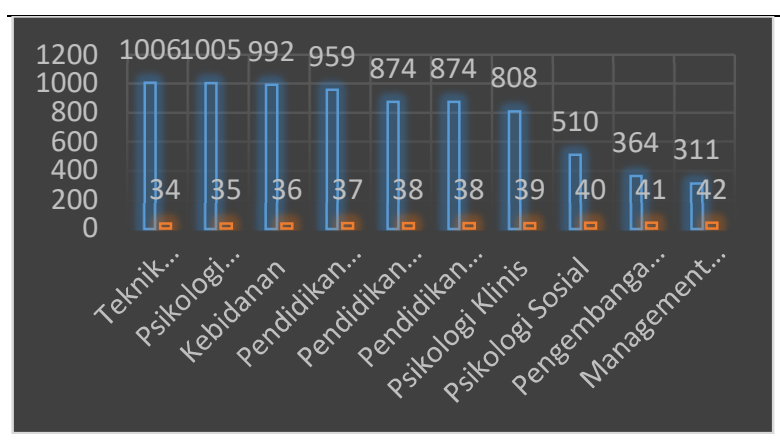

Gambar 3. 10 Prodi Paling Kurang Diminati

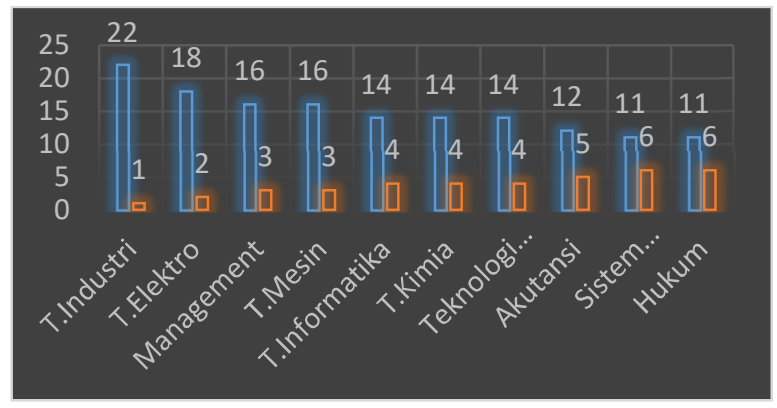

Gambar 4. 10 Prodi Paling Dibutuhkan Perusahaan

Cluster analisis disini digunakan untuk menganalisa kelompok pekerjaan yang memiliki karakteristik sama, dalam hal pembukaan lapangan kerja. Gambar 5 menunjukkan 7 cluster terbentuk. Diketahui bahwa kelompok pekerjaan administrasi memiliki karakteristik yang sama dengan kelompok pekerjaan pemasaran. Hal tersebut dapat diidentifikasi bahwa pekerjaan 
administrasi memiliki kedekatan intrinsik dengan pekerjaan pemasaran. Disusul oleh management yang memiliki kemiripan dengan kelompok Administrasi dan pemasaran.Kelompok pekerjaan Engineer \& IT memiliki karakteristik yang sama dengan kelompok pekerjaan analyst. Dan kelompok pekerjaan product \& QC memiliki karakteristik yang hampir sama dengan tim kesehatan

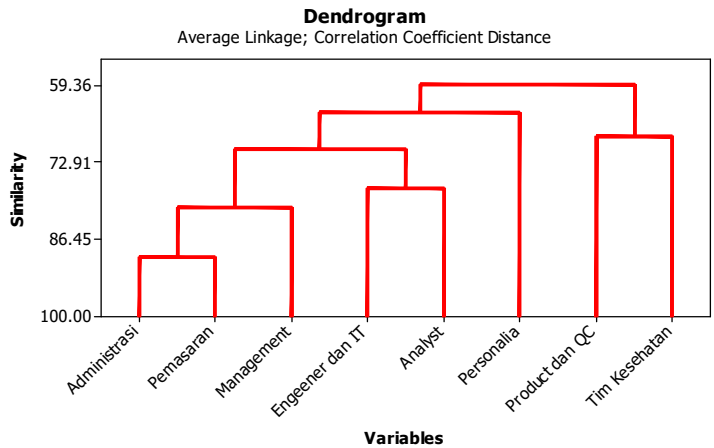

Gambar 5. Cluster Analisis Kelompok Kerja

Korelasi antara minat masuk mahasiswa dalam memilih program studi dengan jumlah loker yang tersedia dapat dijelaskan korelasi antara minat masuk perguruan tinggi dengan jumlah lowongan kerja cukup berkorelasi tetapi tidak kuat dengan nilai 0,560 . Probabilitas bernilai 0,007 kurang dari 0,05 sehingga dapat dipastikan adanya korelasi antar kedua variabel ini (Tabel 2).

Tabel 2. Korelasi

\begin{tabular}{llrr}
\hline & & $\begin{array}{c}\text { Minat } \\
\text { Prodi }\end{array}$ & \multicolumn{2}{c}{ Loker } \\
\hline Minat & Pearson & 1 & $.560^{* *}$ \\
_Prodi & Correlation & & .007 \\
& Sig. (2-tailed) & & 22 \\
& N & 22 & 1 \\
Loker & Pearson & $.560^{* *}$ & \\
& Correlation & & \\
& Sig. (2-tailed) & .007 & 43 \\
& $\mathrm{~N}$ & 22 & \\
\hline
\end{tabular}

Tahap selanjutnya setelah ada korelasi antara variabel dependent dan independent, maka akan dilakukan analisis pada regresi liniernya untuk membentuk model. Output yang dihasilkan dari analisa dengan software SPSS, memperlihatkan bahwa nilai $R$ square $31,4 \%$ yang artinya variasi minat masuk dapat dijelaskan oleh variabel lowongan kerja sebesar 31,4\% (tabel 3) yang menunjukkan banyak variabel lain yang sangat mempengaruhi jumlah minat. Tapi karena analisa dalam penelitian ini adalah mencari irisan antara jumlah minat masuk prodi dan kebutuhan prodi akan perusahaan, maka model ini tetap dipertahankan. Hasil dari uji ANOVA menunjukkan $F_{\text {hitung }}$ memperlihatkan nilai 9,156, dan nilai probabilitas menghasilkan nilai 0,007 atau kurang dari 0,05 (Tabel 4) sehingga dapat diasumsikan bahwa model regresi bisa digunakan untuk memprediksi jumlah minat masuk perguruan tinggi di wilayah Gresik.

Tabel 3. Model Summary

\begin{tabular}{llrrr}
\hline Model & $\mathbf{R}$ & $\begin{array}{c}\mathbf{R} \\
\text { Square }\end{array}$ & $\begin{array}{r}\text { Adjusted } \\
\text { R Square }\end{array}$ & Std. Error of the Estimate \\
\hline 1 & $.560^{\mathrm{a}}$ & .314 & .280 & 743.38065 \\
\hline
\end{tabular}

Tabel 4. ANOVA

\begin{tabular}{|c|c|c|c|c|c|c|}
\hline \multicolumn{2}{|c|}{ Model } & \multirow{2}{*}{$\begin{array}{l}\begin{array}{l}\text { Sum of } \\
\text { Squares }\end{array} \\
5059857.612\end{array}$} & \multirow[t]{2}{*}{ df } & \multirow{2}{*}{$\begin{array}{l}\text { Mean Square } \\
5059857.612\end{array}$} & \multirow{2}{*}{$\begin{array}{l}\mathbf{F} \\
9.156\end{array}$} & \multirow{2}{*}{$\begin{array}{l}\text { Sig. } \\
.007^{\mathrm{b}}\end{array}$} \\
\hline & Regression & & & & & \\
\hline \multirow[t]{2}{*}{1} & Residual & 11052295.706 & 20 & 552614.785 & & \\
\hline & Total & 16112153.318 & 21 & & & \\
\hline
\end{tabular}

Tabel 5. Coefficients

\begin{tabular}{llrrrrr}
\hline Model & \multicolumn{2}{c}{$\begin{array}{c}\text { Unstandardized } \\
\text { Coefficients } \\
\text { B }\end{array}$} & \multicolumn{1}{c}{ Std. Error } & $\begin{array}{l}\text { Stand. } \\
\text { Coeff } \\
\text { Beta }\end{array}$ & T & Sig. \\
\hline 1 & $\begin{array}{l}\text { (Consta } \\
\text { nt) }\end{array}$ & 655.544 & 374.895 & & 1.749 & .096 \\
& Loker & 159.275 & 52.637 & .560 & 3.026 & .007 \\
\hline
\end{tabular}

Tabel 5 memperlihatkan nilai parameter model yang digunakan dalam pembentukan model. Model yang didapat dari analisa ini adalah

\section{$Y=655,544+159,275 X_{1}$}

Interpretasi yang bisa dijelaskan oleh model adalah setiap penambahan satu-satuan lowongan kerja, maka jumlah minat mahasiswa akan bertambah sebesar 160 . Sedangkan nilai 656 adalah penambahan jumlah minat dijelaskan oleh variabel lain yang tidak disebutkan dalam penelitian.

\section{Analytical Hierarchy Process (AHP)}

Tahap awal yang dianalisa pada penelitian ini adalah mencari nilai eigen pada matrik lowongan kerja. Hasil perhitungan eigen menggunakan excel memperlihatkan bahwa kelompok administrasi memiliki nilai tertinggi daripada kelompok lainnya. Hal tersebut bisa diidentifikasikan bahwa kelompok administrasi memiliki jenis pekerjaan cukup banyak sebagai penyumbang penyerapan tenaga kerja (Tabel 6).

Tahap selanjutnya adalah tahap mencari nilai eigen dari matrik program studi dari kelompok administrasi. Matrik eigen jurusan dari kelompok administrasi. Dari analisa yang dilakukan, kelompok pekerjaan administrasi paling banyak menyerap lulusan dari Prodi Akutansi, Management dan Teknik Industri (Tabel 7). nilai 
perhitungan matrik eigen penyerapan tenaga kerja dilihat dari prodi lulusan. Dari kelompok pemasaran diketahui bahwa penyerapan tenaga kerja berasal dari Prodi Akutansi, Management dan Teknik Industri (Tabel 8)

Tabel 6. Tabel Matrik Eigen Kelompok Kerja

\begin{tabular}{|c|c|c|c|c|}
\hline Loker & $\begin{array}{c}\text { Admi- } \\
\text { nistrasi }\end{array}$ & $\cdots$ & $\begin{array}{c}\text { Tim } \\
\text { Kesehatan }\end{array}$ & Eigen \\
\hline $\begin{array}{c}\text { Admi- } \\
\text { Nistrasi }\end{array}$ & 1,00 & $\ldots$ & 4,00 & 0,222 \\
\hline $\begin{array}{l}\text { Pema- } \\
\text { Saran }\end{array}$ & 0,38 & $\ldots$ & 1,50 & 0,083 \\
\hline $\begin{array}{c}\text { Perso- } \\
\text { Nalia }\end{array}$ & 0,50 & $\cdots$ & 2,00 & 0,111 \\
\hline $\begin{array}{l}\text { Engineer } \\
\quad \& \text { IT }\end{array}$ & 0,88 & $\cdots$ & 3,50 & 0,194 \\
\hline $\begin{array}{l}\text { Manage- } \\
\text { Ment }\end{array}$ & 0,63 & $\cdots$ & 2,50 & 0,139 \\
\hline Analyst & 0,13 & $\cdots$ & 0,50 & 0,028 \\
\hline $\begin{array}{l}\text { Product } \\
\text { \& QC }\end{array}$ & 0,75 & $\cdots$ & 3,00 & 0,167 \\
\hline $\begin{array}{c}\text { Tim } \\
\text { Kesehatan }\end{array}$ & 0,25 & $\cdots$ & 1,00 & 0,056 \\
\hline Total & 4,50 & $\cdots$ & 18,00 & \\
\hline
\end{tabular}

Tabel 7. Tabel Matrik Eigen Prodi Dari Kelompok Administrasi

\begin{tabular}{ccccc}
\hline Administrasi & $\begin{array}{c}\text { Teknologi } \\
\text { Pangan }\end{array}$ & $\ldots$ & T.Informatika & Eigen \\
\hline $\begin{array}{c}\text { Teknologi } \\
\text { Pangan }\end{array}$ & 1,000 & $\ldots$ & 2,000 & $\mathbf{0 , 0 5 8}$ \\
Agrotek- & 0,500 & $\ldots$ & 1,000 & $\mathbf{0 , 0 2 9}$ \\
Nologi & & $\ldots$ & 2,000 & $\mathbf{0 , 0 5 8}$ \\
Agribisnis & 1,000 & $\ldots$ & 2,00 \\
$\begin{array}{c}\text { Man.S. Daya } \\
\text { Lahan }\end{array}$ & 0,500 & $\ldots$ & 0,333 & $\mathbf{0 , 0 2 1}$ \\
$\begin{array}{c}\text { Agronomi dan } \\
\text { Holtikultura }\end{array}$ & 0,500 & $\ldots$ & 1,000 & $\mathbf{0 , 0 2 9}$ \\
Hukum & 0,500 & $\ldots$ & 1,000 & $\mathbf{0 , 0 2 9}$ \\
\hline Akutansi & 2,000 & $\ldots$ & 4,000 & $\mathbf{0 , 1 1 5}$ \\
Management & 2,000 & $\ldots$ & 4,000 & $\mathbf{0 , 1 1 5}$ \\
\hline $\begin{array}{c}\text { Ekonomi } \\
\text { Pembangunan }\end{array}$ & 1,000 & $\ldots$ & 2,000 & $\mathbf{0 , 0 5 8}$ \\
T.Kimia & 1,500 & $\ldots$ & 3,000 & $\mathbf{0 , 0 8 6}$ \\
T. Elektro & 1,000 & $\ldots$ & 2,000 & $\mathbf{0 , 0 5 8}$ \\
T.Sipil & 1,000 & $\ldots$ & 2,000 & $\mathbf{0 , 0 5 8}$ \\
\hline T.Industri & 2,000 & $\ldots$ & 4,000 & $\mathbf{0 , 1 1 5}$ \\
\hline T.Informatika & 1,500 & $\ldots$ & 3,000 & $\mathbf{0 , 0 8 6}$ \\
\hline T.Mesin & 1,000 & $\ldots$ & 2,000 & $\mathbf{0 , 0 5 8}$ \\
T.Informatika & 0,500 & $\ldots$ & 1,000 & $\mathbf{0 , 0 2 9}$ \\
\hline Total & $\mathbf{1 7 , 5 0 0}$ & $\ldots$ & $\mathbf{3 4 , 3 3 3}$ & \\
\hline
\end{tabular}

Tabel 8. Tabel Matrik Eigen Prodi Dari Kelompok Pemasaran

\begin{tabular}{ccccc}
\hline Pemasaran & $\begin{array}{c}\text { Teknologi } \\
\text { Pangan }\end{array}$ & $\ldots$ & T.Informatika & Eigen \\
\hline Teknologi & 1,000 & $\ldots$ & 1,000 & 0,056 \\
$\begin{array}{c}\text { Pangan } \\
\text { Agroteknologi }\end{array}$ & 1,000 & $\ldots$ & 1,000 & 0,056 \\
$\begin{array}{c}\text { Agribisnis } \\
\text { Man.Sumber }\end{array}$ & 1,000 & $\ldots$ & 1,000 & 0,056 \\
$\begin{array}{c}\text { Daya Lahan } \\
\text { Agronomi dan }\end{array}$ & 1,000 & $\ldots$ & 1,000 & 0,056 \\
Holtikultura & 1,000 & $\ldots$ & 1,000 & 0,056 \\
$\begin{array}{c}\text { Proteksi } \\
\text { Tanam }\end{array}$ & 1,000 & $\ldots$ & 1,000 & 0,056 \\
Akutansi & 2,000 & $\ldots$ & 2,000 & 0,111 \\
Management & 2,000 & $\ldots$ & 2,000 & 0,111 \\
\hline $\begin{array}{c}\text { Ekonomi } \\
\text { Pembangunan }\end{array}$ & 1,000 & $\ldots$ & 1,000 & 0,056 \\
Ekonomi & 1,000 & $\ldots$ & 1,000 & 0,056 \\
Islam & 1,000 & $\ldots$ & 1,000 & 0,056 \\
T.Kimia & 1,000 & $\ldots$ & 1,000 & 0,056 \\
T.Elektro & 1,000 & $\ldots$ & 2,000 & 0,111 \\
\hline T.Industri & 2,000 & $\ldots$ & 1,000 & 0,056 \\
\hline T.Mesin & 1,000 & $\ldots$ & 1,000 & 0,056 \\
\hline T.Informatika & 1,000 & $\ldots$ & 18,00 & \\
\hline Total & $\mathbf{1 8 , 0 0}$ & $\ldots$ & & \\
\hline
\end{tabular}

Nilai perhitungan matrik eigen pada penyerapan tenaga kerja menurut jenis lulusan program studi. Terlihat bahwa pada kelompok personalia, penyerapan tenaga kerja paling banyak adalah pada lulusan program studi Psikologi Industri, Hukum dan Teknik Industri (Tabel 9). Nilai perhitungan matrik eigen pada penyerapan tenaga kerja menurut jenis lulusan program studi. Terlihat bahwa pada kelompok Teknik dan IT, penyerapan tenaga kerja paling banyak adalah pada lulusan program studi Teknik Elektro, Teknik Informatika dan Sistem Informasi (Tabel 10).

Tabel 9. Tabel Matrik Eigen Prodi Dari Kelompok Personalia

\begin{tabular}{ccccc}
\hline Personalia & $\begin{array}{c}\text { Psikologi } \\
\text { Industri }\end{array}$ & $\ldots$ & T.Mesin & Eigen \\
\hline Psikologi & 1,000 & $\ldots$ & 2,000 & $\mathbf{0 , 2 1 1}$ \\
Industri & 1,250 & $\ldots$ & 2,500 & $\mathbf{0 , 2 6 3}$ \\
Hukum & 0,250 & $\ldots$ & 0,500 & $\mathbf{0 , 0 5 3}$ \\
Management & 0,250 & $\ldots$ & 0,500 & $\mathbf{0 , 0 5 3}$ \\
Kewirausahaan & 0,250 & $\ldots$ & 0,500 & $\mathbf{0 , 0 5 3}$ \\
Ekonomi & 0,250 & $\ldots$ & 0,500 & $\mathbf{0 , 0 5 3}$ \\
Pembangunan & $\mathbf{0 , 0 5 0}$ & $\ldots, 000$ & $\mathbf{0 , 2 1 1}$ \\
T.Elektro & $\mathbf{1 , 0 0 0}$ & $\ldots$ & 2,000 \\
T.Industri & 0,500 & $\ldots$ & 1,000 & $\mathbf{0 , 1 0 5}$ \\
\hline T.Mesin & $\mathbf{4 , 7 5}$ & $\ldots$ & $\mathbf{9 , 5 0}$ & \\
\hline
\end{tabular}

Tabel 10. Tabel Matrik Eigen Prodi Dari Kelompok Teknik \& IT 


\begin{tabular}{ccccc}
\hline $\begin{array}{c}\text { Teknik } \\
\& \text { IT }\end{array}$ & Tek.Pangan & $\ldots$ & Gizi & Eigen \\
\hline $\begin{array}{c}\text { Tek.Pangan } \\
\text { Pend. }\end{array}$ & 1,0000 & $\ldots$ & 1,0000 & 0,0370 \\
Matematika & 1,0000 & $\ldots$ & 1,0000 & 0,0370 \\
Akutansi & 1,0000 & $\ldots$ & 1,0000 & 0,0370 \\
Management & 1,0000 & $\ldots$ & 1,0000 & 0,0370 \\
Ekonomi & 1,0000 & $\ldots$ & 1,0000 & 0,0370 \\
Pembangunan & 3,0000 & $\ldots$ & 3,0000 & 0,1111 \\
T.Kimia & 4,0000 & $\ldots$ & 4,0000 & 0,1481 \\
\hline T.Elektro & 1,0000 & $\ldots$ & 1,0000 & 0,0370 \\
T.Industri & 4,0000 & $\ldots$ & 4,0000 & 0,1481 \\
T.Informatika & 3,0000 & $\ldots$ & 3,0000 & 0,1111 \\
\hline T.Mesin & 4,0000 & $\ldots$ & 4,0000 & 0,1481 \\
Sistem & 2,0000 & $\ldots$ & 2,0000 & 0,0741 \\
Informatika & 1,0000 & $\ldots$ & 1,0000 & 0,0370 \\
\hline Multimedia & 27 & $\ldots$ & 27 & \\
\hline Gizi & & & &
\end{tabular}

Nilai perhitungan matrik eigen pada penyerapan tenaga kerja menurut jenis lulusan program studi. Terlihat bahwa pada kelompok Management, penyerapan tenaga kerja paling banyak adalah pada lulusan program studi Teknik Industri dan yang kedua adalah Program Studi Managemet sendiri (Tabel 11). Nilai perhitungan matrik eigen pada penyerapan tenaga kerja menurut jenis lulusan program studi. Terlihat bahwa pada kelompok Analyst, prodi dibutuhkan untuk penyerapan tenaga kerja memiliki bobot yang sama. Jenis prodi yang masuk dalam kelompok ini adalah Prodi Akutansi, Teknik Kimia, Teknik Industri, Teknik Informatika dan Sistem Informasi (Tabel 12).

Tabel 11. Tabel Matrik Eigen Prodi Dari Kelompok Management

\begin{tabular}{ccccc}
\hline Management & Tek.Pangan & $\ldots$ & T.Mesin & Eigen \\
\hline Tek.Pangan & 1,000 & $\ldots$ & 1,000 & 0,0526 \\
Agribisnis & 1,000 & $\ldots$ & 1,000 & 0,0526 \\
Pend.Bhs. & 1,000 & $\ldots$ & 1,000 & 0,0526 \\
Inggris & 1,000 & $\ldots$ & 1,000 & 0,0526 \\
Hukum & 4,000 & $\ldots$ & 4,000 & 0,2105 \\
Management & 1,000 & $\ldots$ & 1,000 & 0,0526 \\
Kewirausahaan & 1,000 & $\ldots$ & 1,000 & 0,0526 \\
Ekonomi & 2,000 & $\ldots$ & 2,000 & 0,1053 \\
Pembangunan & 5,000 & $\ldots$ & 5,000 & 0,2632 \\
T.Elektro & 1,000 & $\ldots$ & 1,000 & 0,0526 \\
T.Industri & 1,000 & $\ldots$ & 1,000 & 0,0526 \\
\hline T.Informatika & 19 & $\ldots$ & 19 & \\
T.Mesin & \multicolumn{1}{c}{.M. }
\end{tabular}

Tabel 12. Tabel Matrik Eigen Prodi Dari Kelompok Analyst

\begin{tabular}{|c|c|c|c|c|}
\hline Analyst & Akutansi & $\cdots$ & $\begin{array}{c}\text { Sistem } \\
\text { Informasi }\end{array}$ & Eigen \\
\hline Akutansi & 1,00 & $\cdots$ & 1,00 & 0,2 \\
\hline T.Kimia & 1,00 & $\cdots$ & 1,00 & 0,2 \\
\hline T.Industri & 1,00 & $\cdots$ & 1,00 & 0,2 \\
\hline T.Informatika & 1,00 & $\cdots$ & 1,00 & 0,2 \\
\hline $\begin{array}{c}\text { Sistem } \\
\text { Informasi }\end{array}$ & 1,00 & $\cdots$ & 1,00 & 0,2 \\
\hline & 5,00 & $\cdots$ & 5,00 & \\
\hline
\end{tabular}

Nilai perhitungan matrik eigen pada penyerapan tenaga kerja menurut jenis lulusan program studi. Terlihat bahwa pada kelompok Product dan QC, prodi yang paling banyak dibutuhkan untuk kelompok ini adalah prodi Teknologi Pangan, Agroteknologi dan Agronomi dan Hortikultura (Tabel 13). Nilai perhitungan matrik eigen pada penyerapan tenaga kerja menurut jenis lulusan program studi. Terlihat bahwa pada kelompok Tim Kesehatan, prodi yang paling banyak dibutuhkan untuk kelompok ini adalah Prodi Keperawatan. Sedangkan untuk Prodi Farmasi dan Pendidikan Dokter memiliki nilai bobot yang sama setelah Prodi Keperawatan (Tabel 14).

Tabel 13. Tabel Matrik Eigen Prodi Dari Kelompok Product \& QC

\begin{tabular}{ccccc}
\hline $\begin{array}{c}\text { Product \& } \\
\text { QC }\end{array}$ & $\begin{array}{c}\text { Tek. } \\
\text { Pangan }\end{array}$ & $\ldots$ & $\begin{array}{c}\text { Proteksi } \\
\text { Tanaman }\end{array}$ & Eigen \\
\hline Tek.Pangan & 1,000 & $\ldots$ & 3,000 & 0,214 \\
\hline Akuakultur & 0,333 & $\ldots$ & 1,000 & 0,071 \\
Agroteknologi & 1,000 & $\ldots$ & 3,000 & 0,214 \\
Agribisnis & 0,333 & $\ldots$ & 1,000 & 0,071 \\
Man.SD & 0,667 & $\ldots$ & 2,000 & 0,143 \\
$\quad$ Lahan & & $\ldots$ & & 0,214 \\
Agronomi dan & 1,000 & $\ldots, 000$ & \\
Holtikultura & & & & \\
Proteksi & 0,333 & $\ldots$ & 1,000 & 0,071 \\
Tanaman & & & & \\
\hline
\end{tabular}

Tabel 14. Tabel Matrik Eigen Prodi dari Kelompok Tim Kesehatan

\begin{tabular}{ccccc} 
Tim Kesehatan & T.Elektro & $\cdots$ & $\begin{array}{c}\text { Pend. } \\
\text { Dokter }\end{array}$ & Eigen \\
\hline T.Elektro & 1,00 & $\ldots$ & 0,50 & 0,111 \\
Keperawatan & 3,00 & $\ldots$ & 1,50 & 0,333 \\
Farmasi & 2,00 & $\ldots$ & 1,00 & 0,222 \\
Fisioterapi & 1,00 & $\ldots$ & 0,50 & 0,111 \\
Pend.Dokter & 2,00 & $\ldots$ & 1,00 & 0,222 \\
\hline & $\mathbf{9 , 0 0}$ & $\ldots$ & $\mathbf{4 , 5 0}$ & \\
\hline
\end{tabular}

Tahap selanjutnya adalah menganalisa rank dari seluruh program studi terpilih dengan. Caranya adalah mengalikan nilai eigen dari hasil 
matrik tiap kelompok kerja dengan eigen kelompok kerja sendiri (Tabel 15) dengan rangking tertinggi adalah program studi manajemen. Kelompok tertinggi berdasarkan penyerapan tenaga kerja dan peminatan masuk prodi diperoleh jurusan farmasi mempunyai nilai yang paling tinggi (Tabel 16).

Tabel 15. Hasil Rank Nilai Prodi Tiap Kelompok Kerja

\begin{tabular}{|c|c|c|c|c|c|}
\hline Jurusan & Bobot & Rank & Jurusan & Bobot & Rank \\
\hline $\begin{array}{l}\text { Teknologi } \\
\text { Pangan }\end{array}$ & 0,067 & 3 & Sipil & 0,036 & 11 \\
\hline Akutansi & 0,043 & 9 & $\begin{array}{c}\text { Sistem } \\
\text { Informasi }\end{array}$ & 0,030 & 14 \\
\hline Management & 0,077 & 1 & $\begin{array}{l}\text { Proteksi } \\
\text { Tanaman }\end{array}$ & 0,012 & 23 \\
\hline $\begin{array}{c}\text { Ekonomi } \\
\text { Pembanguna } \\
n\end{array}$ & 0,038 & 10 & $\begin{array}{l}\text { Psikologi } \\
\text { Industri }\end{array}$ & 0,023 & 15 \\
\hline T.Elektro & 0,068 & 2 & $\begin{array}{c}\text { Kewirausahaa } \\
n\end{array}$ & 0,013 & 20 \\
\hline T.Industri & 0,067 & 4 & $\begin{array}{l}\text { Ekonomi } \\
\text { Islam }\end{array}$ & 0,006 & 28 \\
\hline T.Informatika & 0,061 & 5 & Keperawatan & 0,018 & 18 \\
\hline T.Mesin & 0,058 & 6 & Farmasi & 0,012 & 21 \\
\hline
\end{tabular}

Tabel 16. Rank Eigen Penyerapan Tenaga Kerja dan Minat Masuk Prodi

\begin{tabular}{|c|c|c|c|c|c|}
\hline Eigen & $\begin{array}{l}\text { Rank } \\
\text { Eigen }\end{array}$ & Prodi & Eigen & $\begin{array}{l}\text { Rank } \\
\text { Eigen }\end{array}$ & Prodi \\
\hline 0,032 & 16 & $\begin{array}{l}\text { Teknologi } \\
\text { Pangan }\end{array}$ & 0,020 & 19 & Sipil \\
\hline 0,037 & 14 & Akutansi & 0,020 & 19 & $\begin{array}{c}\text { Sistem } \\
\text { Informasi }\end{array}$ \\
\hline 0,062 & 4 & Management & 0,055 & 7 & $\begin{array}{l}\text { Proteksi } \\
\text { Tanaman }\end{array}$ \\
\hline 0,027 & 18 & $\begin{array}{c}\text { Ekonomi } \\
\text { Pembangunan }\end{array}$ & 0,057 & 6 & $\begin{array}{l}\text { Psikologi } \\
\text { Industri }\end{array}$ \\
\hline 0,040 & 13 & T.Elektro & 0,012 & 24 & $\begin{array}{c}\text { Kewirausahaa } \\
n\end{array}$ \\
\hline 0,052 & 8 & T.Industri & 0,015 & 23 & $\begin{array}{l}\text { Ekonomi } \\
\text { Islam }\end{array}$ \\
\hline 0,060 & 5 & T.Informatika & 0,050 & 9 & Keperawatan \\
\hline 0,035 & 15 & T.Mesin & 0,070 & 1 & Farmasi \\
\hline 0,020 & 19 & Agroteknologi & 0,007 & 26 & Fisioterapi \\
\hline 0,042 & 11 & Agribisnis & 0,067 & 2 & $\begin{array}{l}\text { Pendidikan } \\
\text { Dokter }\end{array}$ \\
\hline 0,010 & 25 & $\begin{array}{c}\text { Management } \\
\text { Sumber Daya } \\
\text { Lahan }\end{array}$ & 0,005 & 27 & $\begin{array}{l}\text { Pendidikan } \\
\text { Matematika }\end{array}$ \\
\hline 0,002 & 28 & $\begin{array}{l}\text { Agronomi dan } \\
\text { Holtikultura }\end{array}$ & 0,042 & 11 & $\begin{array}{c}\text { Pendidikan } \\
\text { Bahasa Inggris }\end{array}$ \\
\hline 0,047 & 10 & Hukum & 0,017 & 22 & $\begin{array}{c}\text { Multimedia } \\
\text { dan Jaringan }\end{array}$ \\
\hline 0,030 & 17 & Kimia & 0,065 & 3 & Ilmu Gizi \\
\hline
\end{tabular}

\section{KESIMPULAN}

Berdasarkan pengolahan data, dari rank minat masuk mahasiswa, prodi yang paling diminati dari 100 siswa-siswi yang melakukan survey dengan diminta mengurutkan seluruh alternatif program studi yang ada, maka prodi yang paling banyak diminati adalah Prodi Farmasi, Pendidikan Dokter dan Ilmu Gizi. Cluster analisis menunjukkan bahwa kelompok kerja
Administrasi dan Pemasaran memiliki karakteristik yang sama. Kelompok kerja Engineer \& IT memiliki karakteristik yang sama. Kelompok kerja Product \& QC dan Tim Kesehatan memiliki karakteristik kerja yang sama. Berdasarkan perhitungan eigen dari rank prodi paling diminati siswa-siswi SMA dan penyerapan tenaga kerja paling banyak adalah Prodi Farmasi, Pendidikan Dokter dan Ilmu Gizi. Penelitian selanjutnya dapat dilakukan dengan menggunakan sampling siswa yang mempunyai keminatan untuk lanjut kuliah sehingga hasilnya bisa mendekati kebenaran dengan kondisi Gresik.

\section{DAFTAR PUSTAKA}

Drapper, N. R., \& Smith, H. (1992). Analisis Regresi Terapan (Edisi Kedua). Jakarta :PT. Gramedia Pustaka Utama.

Ediyanto, M. N. M., \& Satyahadewi, N. (2013). Pengklasifikasian Karakteristik Dengan Metode K-Means Cluster Analysis. BIMASTER, 2(02), 133-136. https://jurnal.untan.ac.id/index.php/jbmstr/ar ticle/view/3033

Forman, E. H., \& Gass, S. I. (2001). The Analytic Hierarchy Process-An Exposition. Operations Research, 49(4), 469-486. https://doi.org/10.1287/opre.49.4.469.11231

Gudono. (2011). Analisis data multivariat. Yogyakarta: BPEE.

Hair, J., Black, W. C., Babin, B. J., \& Anderson, R. E. (2010). Multivariate Data Analysis. New Jersey: Pearson Education, Inc.

Marsono. (2020). Penggunaan Metode Analytical Hierarchy Process ( Ahp ) dalam Penelitian. Bogor: In Media.

Masykuroh, N., Peristiwo, H., \& Suganda, A. D. (2019). Pengembangan Jurusan Zakat Dan Wakaf Pada UIN SMH Banten. Akutansi Bisnis \& Manajemen ( ABM ), 26(02), 104121.

https://doi.org/10.35606/jabm.v26i02.454

Permana, S. B. (2013). Sistem Pendukung Keputusan Pemilihan Program Studi di UIN Sunan Kalijaga Menggunakan Metode Analytical Hierarchy Process (AHP) [UIN Sunan Kalijaga Yogyakarta]. http://digilib.uin-suka.ac.id/9057/

Saaty, T. L. (1990). Decision making for leaders: the analytic hierarchy process for decisions in a complex world. RWS publications.

Satyawan, I. M., Kardiawan, K. H., \& Kusuma, K. C. A. (2020). Studi Kelayakan Pembentukan Program Studi Pendidikan Jasmani Pendidikan Guru Sekolah Dasar (PJ PGSD) Tahun 2019. Jurnal IKA, 18(1), 73-84. https://ejournal.undiksha.ac.id/index.php/IK A/article/view/28385 
Soekiyono, Pujiastuti, S. L., Mashithoh, H., \& Mulyana, A. (2014). Studi Kelayakan Pembukaan Program Studi Strata Satu Manajemen Perhotelan dan Pariwisata pada Fakultas Ekonomi Universitas Terbuka. http://repository.ut.ac.id/5946/

Supranto, J. (2004). Analisis Multivariat Arti dan Interpretasi. Jakarta: Rineka Cipta.

Syafar, A. M. (2018). Sistem Pengambilan Keputusan Memilih Program Studi Di Uin Alauddin Berbasis Web Dengan Metode Analytic Hierarcy Process (AHP). Jurnal INSTEK (Informatika Sains Dan Teknologi), 3(2), 309-318. http://journal.uinalauddin.ac.id/index.php/instek/article/view/ 6572

Wahyudi, A., Barusman, M. Y. S., \& Waskito, B. (2012). Analisis Model Decision Support System (DSS) untuk Pembukaan Program Studi Jenjang S2 di Universitas Bandar Lampung. VISIONIST, 1(2), 111-125. http://jurnal.ubl.ac.id/index.php/jmv/article/vi ew/669

Walpole, R. E., \& Myers, R. H. (1995). IImu Peluang dan Statistika untuk Insinyur dan Ilmuwan edisi keempat. Bandung: Institut Teknologi Bandung. 